\title{
BLASPHEMY AS A THICK CONCEPT
}

\author{
OSCAR PÉREZ DE LA FUENTE*
}

\begin{abstract}
Thick concepts have been central in metaethical debates over the last few decades, for instance in the controversy between cognitivism and non-cognitisivism or in the fact/value distinction. They are characterised as world guided, action guiding and community shared. In this paper, thick concepts are used to analyse case law on blasphemy from the European Court of Human Rights. When conducting this analysis, the test of civility proposed by Habermas and Rawls will also be applied. Public reason obligates the use of reasons accessible to all, that is to say not with a particular/thick meaning, in the public sphere.
\end{abstract}

Keywords: blasphemy, religious insult, hatred for religious reasons, test of civility, thick concepts

Summary: 1. Free SPeECh AND Religion. 2. What are 'Thick Concepts'? 2.1. Thick concepts as 'world guided'. 2.2. Thick concepts as 'action guiding'. 2.3. Thick concepts as 'community shared'. 2.4. Some objections to thick concepts' approach. 3. Blasphemy IN THE EuropeAn COURT OF hUMAN RIGHTS CASE LAw. 3.1. X Ltd. and Y v. United Kingdom 7 May 1982. 3.1. a) Test of thick concepts. 3.1. b) Test of civility. 3.2. Choudhury v. United Kingdom 5 March 1991. 3.2. a) Test of thick concepts. 3.2. b) Test of civility. 3.3. Case Otto-Preminger Institut v. Austria 20 September 1994. 3.3. a) Test of thick concepts. 3.3. b) Test of civility. 3.4. Wingrove v. United Kingdom 25 November 1996. 3.4. a) Test of thick concepts. 3.4. b) Test of civility. 3.5. Samina v. Sweden 20 October 2011. 3.5. a) Test of thick concepts. 3.5. b) Test of civility. 3.6. Case I.A. v. Turkey 13 September 2005. 3.6. a) Test of thick concepts. 3.6. b) Test of civility. 3.7. E.S. v. Austria, 25 October 2018. 3.7. a) Test of thick concepts. 3.7. b) Test of civility. 4. SOME CONCLUSIVE REMARKS.

\section{Free SPEECH AND RELIGION}

The crime of blasphemy has a long history in different societies. As Dacey notes the justification of this crime has changed over time in the West. The first phase, in Ancient times, blasphemy was a direct verbal attack on the divine. The second phase, in the Middle Ages, blasphemy was considered as a seditious challenge to the sanctity of law, the public order or the common good. The third phase, in the Modernity, blasphemy is understood as an offence against the sensibilities, rights or dignity of individual religious believers (Dacey, 2012, 18).

Traditional justifications of blasphemy, as a crime, want to avoid some evils that usually are associated with its tolerance. Levy exposes some of these bad consequences: a) Shedd doubts on orthodox religious truth; b) Endanger the unity of society; c) May lead to public disturbances (Levy, 1995, 3). The link between freedom of religion and free speech is deep and relevant. Blasphemy is an institution with an old history in different religions. In other times, its importance came from maintaining religious orthodoxy and

\footnotetext{
" Lecturer in Philosophy of Law, Instituto de Derechos Humanos "Bartolomé de Las Casas", Universidad Carlos III de Madrid, Spain (oscar@der-pu.uc3m.es).
} 
social peace. Nowadays blasphemy is an old-fashioned crime in Europe because of the growing secularism and the separation between Church and State. Some behaviours are still criminalised to protect minorities from religious insults and the incitement of religious hatred.

There is a Jewish/Christian tradition on blasphemy based on biblical interpretation, but this is difficult to translate into the Islamic religion, which uses different concepts. Levy affirms that, in Jewish thought, blasphemy invariably denoted verbal abuse of God (Levy, 1995, 11). Dacey clarifies that the biblical, Grego Hebraic concept of a direct verbal affront to the divine has no precise equivalent in Islamic tradition, which has been more concerned with idolatry and fidelity to doctrinal truth (Dacey, 2012, 3).

In Islam, there is a special protection of the honour of Muhammad, the founder of that religion. Dacey sates that in the context of the unique social relationship between Muslims and the Prophet Muhammad, however, "insult" had special significance. According to the traditional understanding, while Muhammad was a prophet, tribal leader, war chief, and moral arbiter, he was not divine. He was a human being whose honour had to be protected by public expressions of loyalty and esteem. In traditional Islamic law, insulting the Prophet or Allah was the crime of $s a b b$. Committed by Muslims, it constituted ridda, or apostasy, a repudiation of the faith. Committed by non-Muslims, it violated the terms of their status as dhimis, tolerated and protected second-class subjects of the Islamic state (Dacey, 2012, 3). ${ }^{1}$

Blasphemy could be defined as the "act of expressing contempt or a lack of reverence for God or sacred things" (US Commission on International Religious Freedom, 2014, 1). For the purposes of this research, laws prohibiting blasphemy ("blasphemy laws") include provisions that sanction insulting or defaming religion and seek to punish individuals for allegedly offending, insulting, or denigrating religious doctrines, deities, symbols or "the sacred," or for wounding or insulting religious feelings (Fiss, Kestenbuam, 2017, 5).

In a report of the Venice Commission in 2010, the following conclusions were reached: a) The offence of blasphemy should be abolished (which is already the case in most European states) and should not be reintroduced; b) That it is neither necessary nor desirable to create an offence of religious insult (that is, insult to religious feelings) simpliciter, without the element of incitement to hatred as an essential component; c) The incitement to hatred, including religious hatred, should be the object of criminal sanctions as is the case in almost all European states. In the Commission's view, it would be appropriate to introduce an explicit requirement of intention or recklessness (Venice Commission, 2010, 19-30, 32).

"Blasphemy means speaking evil of sacred matters. Where organised religion exists, blasphemy is taboo" (Levy, 1995, 3). The central issue is whether it is the role of the State to punish this offence or whether it should go unpunished. Prosecution for

\footnotetext{
${ }^{1}$ The concept of blasphemy in Islam is a complex issue. It has been analysed for instance in the following works: Soage, 2006, 363-369; Nassera Zini, 2015; Marshall, 2012; Forte, 1994, 27-68; Nitisor, 2007, 69-79.
} 
blasphemy has often been "treason" against intellectual liberty and freedom of religion. Over the centuries, the sanctions against blasphemy have inhibited, not only religious, but artistic, political, scientific and literary expression (Levy, 1995, 569). Much of the most plausible defence of blasphemy law is that it is necessary to protect religious believers from suffering offence to their feelings (Jones, 1980, 133).

Nowadays the crime of blasphemy doesn't pass the test of civility. It could be considered a test of civility by which an act should be accessible to all - Habermas - or we accept and we think others reasonable accept (Rawls, 1996, 217); this means it does not have a particular meaning. This is especially considered in cases of public reason justifications from religious or philosophical comprehensive doctrines in rawlsanian terms (Rawls, 220-222).

This crime has a particular meaning that could not be translated to civil terms. The offence to God, sacred or saint persons is a notion that might not be accessible to everyone because it has a particular thick meaning. The laws of blasphemy have almost disappeared in European countries, but the offence to religious feelings -so named religious insult- and religious hatred or religious defamation often remain as crimes. These institutions, like religious insult or religious hatred, could be also explained as thick concepts.

Secularism expresses the need for legal choices to be based on secular public reasons, that is, on reasons that are accessible for all, quite apart from their religious beliefs. Religiously grounded reasons have to be "translated" into secular ones (Sajó, 2008, 626). This idea is also defended by Habermas and Rawls and is connected with the notion of public reason. This is one of the core values of liberalism that is based on the separation between Church and State and the State neutrality between different religions or "comprehensive moral doctrines"'(Rawls, 1996, 150-158) in rawlsian terms.

Habermas explains that "the principle of separation of Church and State obliges politicians and officials within political institutions to formulate and justify laws, court rulings, decrees, and measures exclusively in a language that is equally accessible to all citizens" (Habermas, 2014, 122). This means that religious citizens have to translate their convictions to secular values. Habermas tells "this only calls for the epistemic ability to consider one's own religious convictions reflexively from the outside and to connect them with secular views. Religious citizens can certainly acknowledge this 'institutional translation proviso' without having to split their identity into public and private parts the moment they participate in public discourses" (Habermas, 2014, 130).

In the Rawls' view there is a link between public reason and the duty of civility. Both concepts imply that there are some epistemic limitations to political justification. Rawls points out that "public justification is not simply valid reasoning, but an argument addressed to others: it proceeds correctly from premises we accept and think others could reasonably accept to conclusions we think they could also reasonably accept. This meets the duty of civility, since in due course the proviso is satisfied" (Rawls, 1997, 765). ${ }^{2}$

\footnotetext{
${ }^{2}$ As a definition of the duty of civility as a part a public reason, Rawls points out: "this means that each of us must have, and be ready to explain, a criterion of what principles and guidelines we think other citizens
} 
The framework is not complete with the different versions of secularism; Habermas had defended the notion of post-secularism that fits better with the current situation. ${ }^{3}$ In Europe nowadays, there are contrasting views on religious and cultural pluralism. There is a struggle between different types of multiculturalists (Parekh, 1990, 2000; 2008; Modood, 2007, 2010) and different kinds of secularist (Sajó, 2008, 2009; Zucca, 2012) and postsecularist (Habermas, 2005, 2008, 2014; Taylor, 2007, Ungureanu, 2016). ${ }^{4}$ They are all an interpretation of Enlightenment with significant varieties and look for how to manage equality and difference in a democratic society with more emphasis in one of these values.

\section{WHAT ARE 'THICK CONCEPTS'?}

Naturalistic fallacy was first explained by Hume in the Treatise of Human Nature with these words: "when of a sudden I am surpriz'd to find, that instead the usual copulations of propositions, is, and is not, I meet with no proposition that is not connected with an ought, or an ought not." 5 However, in another book called Concerning human understanding and concerning the principles of morals, he talks about concepts, such as: "discretion, caution, enterprise, industry, assiduity, frugality, economy, good sense, prudence, discernment" (Hume, 1988, 242). The peculiarity of these nouns was that they "force an avowal of their merit" (Hume, 1988, 242). This is the first precedent of thick concepts' notion.

The notion of thick concepts first appeared in the book Ethics and the limits of philosophy of Williams, which was first published in 1985 (Williams, 2011). There is a precedent of thick concepts notion in Hare's book, Language of morals, first published in 1952, with the notion of value-words as "words in which the evaluative meaning is secondary to the descriptive" (Hare, 1970).

(who are also free and equal may reasonable be expected to endorse along with us" (Rawls, 1996, 226). Rawls also explains the traits of public reason with these words: "The justices cannot, of course, invoke their own personal morality, nor the ideals and virtues of morality generally. Those they must view as irrelevant. Equally, they cannot invoke their or other religious or philosophical views. Nor can they cite political values without restriction. Rather, they must appeal to the political values they think belong to the most reasonable understanding of the public conception and its political values of justice and public reason. These are values that they believe in good faith, as the duty of civility requires, that all the citizens as reasonable and rational might reasonably be expected to endorse. (Rawls, 1996, 236).

${ }^{3}$ Habermas criticises the construction of a "secularization as a kind of zero-sum game between the capitalistically unbridled productivity of science and technology, on the one hand, and the conservative forces of religion and the church on the other hand. Gains on one side can only be achieved at the expense of the other side and by liberal rules, which act in favour of the driving forces of modernity. This image is inconsistent with a postsecular society which adapts to the fact that religious communities continue to exist in a context of ongoing secularization" (Habermas, 2005, 239).

${ }^{4}$ Although Taylor did not use the term postsecular to describe his own position, it could be deduced that his thought could be included under this label.

${ }^{5}$ Hume continued: "This change is imperceptible; but is, however, of that last consequence. For as this ought, or ought not, expresses some new relation or affirmation, 'tis necessary that it shou'd be observ'd and explain'd; and at the same time that a reason should be given, for what seems altogether inconceivable, how this new relation can be a deduction from others, which are entirely different from it". (Hume, 1990, 469). 
'Thick' —or 'substantive' (Scheffler, 1987, 414) — concepts are distinguished from 'thin' concepts like 'right' or 'good'. Among concepts that have been regarded as thick are "treachery, promise, brutality, courage, coward, lie, gratitude, lewd, perverted, rude, glorious, graceful, exploited, and, of course, many others" (Eslund, 2011, 25). These concepts were analysed by the metaethical debates during the last decades. They are considered as a cognitivist argument (McDowell, 1979, 1984; Dancy, 1995) in front of the non-cognitivism (Hare, 1963, 1970, 1985; Blackburn, 1990, 1992; Väyrynen, 2003), and against the fact-value distinction (Moore, 1993). They are linked with the revitalisation of the ethics of virtue (Slote, 1995, 2011; Hursthouse, 2001; Foot, 2002; Swanton, 2005).

This paper looks to present a version of the thick concepts that could be suitably applied in the rights balance on free speech issues, which is sometimes viewed as especially vague and indeterminate. Thick concepts are at the same time: a) "world guided', b) 'action guiding' and c) 'community-shared'. In the following sections, firstly, these characteristics are analysed and, secondly, they are applied to the European Court of Human Rights blasphemy case law.

\subsection{Thick concepts as 'world guided'}

'World guidedness' and the degree of empirical content differences are consequences, or even causes, of the deeper difference between thin and thick concepts; the former stemming from abstract ethical ideas and the latter reflecting the distinctive character of particular social goods, such as: 'coward', 'lie' 'betrayal', 'brutality', 'honour' and 'gratitude' (Scanlon, 2003, 276-277). Examples of thin concepts, when no anthropological involvement is required, include: 'right', 'good', 'desirable' and 'rational'(Benbaji, Fisch, 2004, 4). Such terms are evidence that thin concepts are evaluative rather than descriptive.

By contrast, thick concepts are words that, by their nature, are more heavily descriptive than evaluative. This does not, however, mean that they lack evaluative meaning. For instance, the words 'tidy' and 'industrious' are usually used to commend. These are called, in Hare's terminology; value-words and it would be erroneous to consider them purely descriptive. They are value-words in a less full sense than 'good' (Hare, 1963, $24-25 ; 1970,121)$.

On this descriptive aspect of thick concepts, Williams states that their application guides how the world is. This means there is a general agreement as to how the concept applies to usual situations; however, irresolvable disagreement continues to reign in a marginal number of cases (Williams, 2011, 156). Williams expressly denies that agreement is sufficient for world-guidedness, and he does not seem to regard actual agreement as strictly necessary either (Scheffler, 1987, 418).

For Foot's analysis, he used the example of the word 'rude': a) it can only be used where certain descriptions apply; b) if "thinking a thing rude" is to be described as having a particular attitude to it, then having an attitude presupposes, in this case, believing that certain conditions are met; c) it is an evaluative word; d) it expresses disapproval; f) it 
is meant to be used when an action is to be discouraged; g) it implies that other things being equal the behaviour to which it is applied will be avoided by the speaker; $h$ ) it is a condemnatory word; i) it has the kind of characteristics upon which non-naturalistic fasten (Foot, 1958, 507-508).

There is a combination of description and evaluation, a property and an attitude: "not mere evaluation, of course, but evaluation in the light of the relevant description (the attitude is adopted to the property-bearer for having the property)" (Dancy, 1995, 263). Thick concepts encompass a property and an attitude that is either pro or con. The Aristotelian virtues, for instance, are thick pro-concepts and the vices are thick conconcepts (Dancy, 1995, 263).

The term 'world-guided' suggests that what distinguishes thick concepts is a kind of objectivity, that judgements using these concepts can express knowledge because (in virtue of their thickness) they make claims about the world -claims that are made true by (hence their proper use "guided by") what the world is like (Scanlon, 2003, 276). Cognitivist claimed for their examples that the interconnection between evaluation and description was beyond non-cognitivism capturing. Non-cognitivism had to see the description as essentially independent of the evaluation in way that made it always accessible for the outsider (Scanlon, 2003, 276).

\subsection{Thick concepts as 'action guiding'}

Thick concepts are guided by the world and this implies there is a descriptive aspect. There is also an evaluative aspect to thick concepts that usually implies a judgement, an attitude and some kind of action. Moore explains that the incorporation of thick concepts into our daily lives provides us with a rationale for our actions (Moore, 2006, 135-36). This means that thick concepts are 'action guiding' and are intrinsically related to the reasons for action (Williams, 2011, 155). They comprise both a tie to reasons and a tie to empirical classification (Gibbard, 2003, 288).

With regard to the evaluative aspect, Moore clarifies the application of a thick concept involves evaluating a given situation, making a judgement based on the circumstances as we perceive them to be, and being able to stand corrected if we have erred when coming to our conclusion (Moore, 2006, 135). These reasons for action could include acts and omissions. Moore highlights an example citing the concept of blasphemy, explaining that properly understanding what blasphemy is gives a reason not to blaspheme (Moore, 2006, 136).

To understand what 'action guiding' is, Gibbard makes a distinction between externalism and internalism on reasons [for action]. An externalist would affirm that an act can only be cruel if it is so deplorable that everyone has reason to abhor it and to shy away from committing it (Gibbard, 2003, 303). On the other hand, an internalist would say: an act is cruel if the people forming a community that uses the concept cruel have reason to recoil at the thought of and, as a consequence, refrain from performing those 
acts. It is irrelevant whether or not the persons committing the acts view them as cruel (Gibbard, 2003, 303).

In Gibbard's explanation, Williams is an internalist who thinks that tormenting a cat is cruel even if the tormentors do not recognise their actions are cruel (Gibbard, 2003, 303). The interesting point is that, from the internalist point of view, the importance of thick concepts cannot be underestimated for using and understading concepts within a certain speakers' community.

\subsection{Thick concepts as 'community shared'}

'Community shared' implies thick concepts need a social world behind them, which gives meaning for agreeing or disagreeing in a specific case. Analytic philosophers have queried the difference between thick concepts, which are context-dependent, and thin concepts, which are context-neutral (Flakne, 2005, 116).

At this point, it is appropriate to remember that moral standards could change in different societies and during different times. Concepts like 'cruel', 'brutal', 'dishonest', 'chaste', 'obscene' are thick concepts that cultures will not always share (Gibbard, 2003, 288; Hare, 1963, 25).

In Ethics and the Limits of Philosophy, Williams contrasted two ways of looking at thick judgements in a hypetraditional society: the objetivist and non-objetivist models.

The 'objectivist model' is the search for truth about values by members of any given society in a local way (Williams, 2011, 163).

The 'non-objectivist model' is the ethnographic approach (Gibbard, 2003, 301), in which the judgements of the members of a society are part of their way of living and create a cultural belonging that unites them. Williams asks whether or not when they use these concepts, they express knowledge about the world. He argues that when the appropriate criteria are used by certain members of the society, they will increase their knowledge (Williams, 2011, 163-164; Gibbard, 2003, 301).

According to Moore, thick ethical concepts can be viewed in two ways: an engaged way and a disengaged way. The engaged way comprises not only the theoretical application of the concept, but also the practical application in one's thoughts about the world and in one's conduct. To understand a thick ethical concept in the disengaged way is to recognise only when the concept would be theoretically applied correctly by oneself and by others (Moore, 2006a, 137).

Moore concludes that ethical knowledge is dependent on "the local perspectives or idiosyncrasies of enquirers" whereas scientific knowledge may not be (Moore, 2006b, XVII). The applicability of a thick concept, for example: bravery, can clearly be established by those who share a common moral culture. Using bravery as an example to share a 
culture means being "sentimentally educated" or linguistically inculcated to recognise the features of a particular thick concept (Flakne, 2005, 118).

Another example is the Sabbath. People who are not Jewish have no difficulty in understanding this concept in the disengaged way. However, only a Jewish person recognising an obligation to keep the Sabbath can appreciate the concept in the engaged way. They can, therefore, by say to live by the concept (Moore, 2006a, 137).

The test of thick concepts consists of different levels:

a) 'World guided': The use of a concept, in a particular context, reflects what the world is like. This has strong metaethical and philosophical implications, but it makes sense as a statement within a certain context.

b) 'Action guiding': There are two main reasons for action: internalism and externalism. An externalist would affirm that an act has certain quality if everyone has reason to abhor it and to shy away from committing it. An internalist would say: an act has a certain quality if the people forming a community that uses the concept and have reason to recoil at the thought of and, as a consequence, refrain from performing those acts. It is irrelevant how the persons committing the acts view them. It must be shown whether the use of a concept in a particular context implies a reason for action to everyone -externalist- or a certain community -internalist-.

c) 'Community shared': There are two main positions: engaged and disengaged. The engaged way encompasses not only the theoretical application of the concept, but also the practical application in one's thoughts about the world and in one's conduct. The disengaged way is to recognise only when the concept would be theoretically applied correctly by oneself and by others. It must be shown whether the use of a concept, in a particular context, implies that someone 'lives the concept' in a theoretical and practical way -engaged- or only in a theoretical way -disengaged-.

Thick concepts are a useful tool to analyse the use of certain concepts in a judicial context. The different positions on thick concepts have different philosophical bases and shed light on how certain members of the judiciary view the world. This has led to criticisms of thick concepts being developed.

\subsection{Some objections to thick concepts' approach}

The first well-known objection to thick concepts came from Oscar Wilde, who responded to an accusation of blasphemy during his trial by affirming: "Blasphemy, sir, is not one of my words". By neither accepting or denying that his actions were blasphemous, Wilde was able to avoid misapplication of the normative judgement associated with blaspheming (Enoch, Toh, 2013, 260).

Commenting on this Wilde's phrase, Gibbard affirms that disagreement is the key because blasphemy has a precise sense only when we can agree or disagree, but if it is not possible to do either, the term is not one of our words (Gibbard, 2003, 289). 
Thick concepts are understood within a speakers' community, but there are people outside this community who may be doubful about the application of thick concepts to certain cases (Gibbard, 2003, 304; Flakne, 2005, 127). Thick concepts are complex, fluid and mobile as they are a mix of religious, cultural and ritual history and so cannot be associated with only one attitude (Blackburn, 1992, 296). First, they are "variableattitude" concepts, since they call for different attitudes on different occasions. Second, they are "multi-attitude" concepts. They can ground, or call for, more than one attitude at the same time) (Dancy, 1995, 265).

Finally, there is an amalgam view, according to Blackburn. This means that the attitude and the description infuse each other, so that at the end, in the repertoire of the mature speaker, the two elements are no longer distinguishable (Blackburn, 1992, 298).

Väyrynen presents the category of objectionable concepts that he defines as "embodying values that one thinks ought not to be endorsed" (Värynen, 2003, 569). The idea is that there is no consensus behind thick concept evaluations and this has several implications that could be summarised as their uselessness and limited practical relevance. Väyrynen points out that "those who use such words as lewd, lascivious and chaste and unchaste typically accept a particular sort of outlook on sexuality which many other people reject because they regard the way of thinking conveyed by the typical uses of these terms as failing to draw genuine evaluative distinctions"(Värynen, 2003, 569).

In the next section some cases of the European Court of human rights on free speech and religion under the thick concepts analysis will be studied.

\section{Blasphemy in the European Court of human rights CaSe law}

There have been several cases on blasphemy and religious insult in the European Court of human rights case law. These cases are explained and analysed in this section with the application of the test of thick concepts and the test of civility. The cases have been ordered chronologically, bar the cases of Samina v. Sweden, I.A. v. Turkey and E. S. v. Austria, where the order has been inverted to enable the latter two to be analysed at the same time given their similar content.

\subsection{Ltd. and Y v. United Kingdom 7 May 1982}

In 1976, Gay News, a British newspaper targeted at the gay community, printed Professor James Kirkup's "The Love that Dares to Speak its Name": a poem describing a Roman centurion's erotic fantasies about the body of Jesus immediately after his death (Mortensen, 1994, 413).

The sexuality of sacred persons is a taboo. In 1976, there were social and religious prejudices to homosexuality. This issue relates, however, to a poem, with literary aspects, aimed at a gay audience, not the general public. As Levy points out: "the centurion, in the discreet phrasing of an appellate judge, describes 'in explicit detail acts of sodomy and fellatio with the body of Christ"” (Levy, 1995, 537). 
For the Court it was clear that this was an offence to religious feelings and there was a need to protect them by Law, even Criminal Law. The Court said:

"if it is accepted that the religious feelings of the citizen may deserve protection against indecent attacks on the matters held sacred by him, then it can also be considered as necessary in a democratic society to stipulate that such attacks, if they attain a certain level of severity, shall constitute a criminal offence triable at the request of the offended person". ${ }^{6}$

\section{1. a) Test of thick concepts}

On thick concepts as 'world-guided' application to this case, we can affirm that sexuality of sacred persons is a taboo. The link of Christ, even in a literary phantasy, with homosexuality could be considered offensive for certain sectors. This was a case from the 70's and it could analysed with the prejudices against homosexuality during that time.

The case was based on a poem about a centurion that includes an erotic fantasy with the body of Christ. It is a literary exercise that expresses the feelings of a third person, not Christ himself. However, some people could criticise that this is blasphemous because a sacred person was not treated with the proper respect, but this could be controversial point. As an example of the world as it is, this poem could be considered blasphemous, with a degree of possible disagreement based on the social consideration of homosexuality.

On thick concepts as 'action-guiding', if someone really embraces the concept of blasphemy, this must imply not to blaspheme. In this case, the point is if the alleged offence really justifies the restriction of the speech. An externalist could maintain that this case is not necessarily action-guiding because "not everyone" has a reason not to blaspheme. The case is a literary work based on a historical personage. However, an internalist who uses the concept of blasphemy could affirm, in this case, the figure of Christ is not treated with the proper respect as sex with sacred persons is taboo.

On thick concepts as 'community-shared', certain believers could find this poem offensive and highly blasphemous, but other believers and non-believers may not necessarily find it so. In this thick concept in a disengaged way application, one could understand this could be a controversial case of blasphemy for certain sectors of Christianity. On the other hand, this thick concept in an engaged way application, for those who lived the concept of Christian blasphemy, could be considered offensive, but this will depend heavily on social prejudices on homosexuality.

\section{1. b) Test of civility}

A poem with an erotic fantasy involving a Roman centurion and Christ. This is literature, which expresses the feelings of third person: a centurion. The offensiveness

${ }^{6}$ X Ltd. and Y v. United Kingdom App no 8710/79 (ECHR, 7 May 1982). 
stems from the fact that one person is considered sacred by the believers, and, in their opinion, there is a kind of attribution that is not appropriate. This reason, however, is not accessible to all, rather it has a specific meaning in specific religious context. The right to free speech and criticism should be predominant

\subsection{Choudhury v. United Kingdom 5 March 1991}

Salman Rushdie wrote a book called The Satanic Verses and it was considered offensive by the Muslim community. An Iran religious leader threatens to kill the author. The writer received the support of the great sectors of the Western societies. On the content, Parekh explains that "the Satanic Verses is thus a work of fantasy, not of pure fiction, of an imaginatively reinterpreted but not a radically reconstituted reality" (Parekh, 1990, 697). We can find an example of controversial parts:

"Muhammad is called a 'smart bastard', a debauchee who, after his wife's death, slept with so many women that his beard turned 'half-white' in a year. Muslims deeply respect Bilal, the emancipated black slave who was the first convert to Islam. Here, he is an 'enormous black monster, with a voice to match his size"'(Parekh, 1990, 697).

There is another example: "there is also a brothel scene in which twelve whores take the names of Muhammad's wives. Rushdie has argued that it was intended to provide a profane antithesis to (and thus to highlight and accentuate) the holy. But since the holy has been treated in a mocking manner throughout the novel, the brothel scene cannot be its antithesis; rather, it is a further expression of the same approach" (Parekh, 1990, 697).

Levy points out, regarding the most controversial point on this issue, that "attributing the Koran to human composition indisputably constitutes blasphemy as a matter of Islamic law. Yet Rushdie went further, if ambiguously, by allowing the inference that Satan was the real author of the Koran, at least of some verses" (Levy, 1995, 560). On the Satanic verses style, Mortensen explains: "the general tone of the book was critical of Islam: it used derogatory names for the prophet Muhammad, it denounced the Islamic moral system and, throughout, Rushdie made liberal use of coarse language" (Mortensen, 1994, 414).

The European Court found against the applicants - British Muslim minorities representatives - when it states that "the freedom of Article 9 of the Convention may extend to guarantee a right to bring any specific form of proceedings against those who, by authorship or publication, offend the sensitivities of an individual or of a group of individuals. The Commission finds no indication in the present case of a link between freedom from interference with the freedoms of Article 9 para. 1 of the Convention and the applicant's complaints" (Mortensen, 1994, 414).

In this case, the key question was how is content relating to a venerated person of a religion offensive when: a) there is a minority of believers of that religion in that country; b) the then current national blasphemy law only protected Christians. 


\section{2. a) Test of thick concepts}

As a 'world-guided' thick concept analysis, the point here is whether blasphemy could extend to offences against Muslim believers. The legal concept of blasphemy at that time was only applicable to the dogmas of the Church of England, the official religion in the United Kingdom. However, could someone who uses the concept of blasphemy also include offences to other religions' believers, who are present in the British society? If blasphemy is a proper thick concept, then it has a descriptive element that explains the world as it is and also has evaluative content. The Satanic verses were not seen as blasphemous by the majority of British society, however there was a degree of disagreement from the Muslim minority.

In this context, is it blasphemous to divulge details about the imagined sex and private life of the Muslim Prophet Muhammad in a literary work? For a non-Muslim it is unlikely to be the case, but Muslims could find this offensive. As 'action-guiding' thick concept, this blasphemy resulted in great protests by Muslim minorities in Western Europe, particularly in British society. They called for equality and neutrality between religions on prosecution of blasphemy. This also resulted death threats from an Iranian leader to the author, Salman Rushdie. On the externalist approach, it could be seen that "not everyone" has a reason not to blaspheme. This case was a literary work about a historical personage. On the internalist approach, it depends on what is the community of reference. For society as a whole, Satanic verses were not under the concept of blasphemy, however the Muslim minority affirmed everyone who blasphemed in this way, would have a reason not to blaspheme.

It is a thick concept that is 'community-shared' by believers and not shared by non-believers. The particularity of this case is the believers are a minority in the society and the blasphemy law only protects offences against the majoritarian religion. There is a problem of neutrality. The case law of the ECHR is especially sensitive with the offence of the religious feelings of the majority of the society, but not necessarily with the minority. This is a kind of legal moralism. On the thick concept disengaged way analysis, it could be understood, but not necessarily shared, that certain ironic literary portraits of religious figures could be seen as offensive for certain minorities. On the thick concept engaged way analysis, for those who live the Muslim blasphemy concept, this is blasphemous and a lack of the proper respect of a venerable figure of their religion.

\section{2. b) Test of civility}

This case was portrayed in a novel that criticised and aired on the side of irony towards Islam and the figure of the Prophet Muhammad. It was a literary attack on the intimacy of a venerable figure of a particular religion. The restriction of speech is not a reason accessible to all, it is a particular reason. The right to free speech and criticism should be predominant. 


\subsection{Case Otto-Preminger Institut v. Austria 20 September 1994}

It is a and iconoclast film about Christianity. The main characters are sacred persons that are sarcastically portrayed. ${ }^{7}$ It' is and experimental film, shown in "art cinema", addressed to a small audience. The announcement is quite clear on the characteristics of the film. The main point of the dissenting opinion of the case is "this audience, moreover, had sufficient opportunity of being warned beforehand about the nature of the film". 8 And "it thus appears that there was little likelihood in the instant case of anyone being confronted with objectionable material unwittingly". 9

The ruling of the European Court considered the seizure and forfeiture of the film by the national authorities lawful. The justification for the ruling was the protection of the religious feelings of the majority of the population. The Sentence said "the Court cannot disregard the fact that the Roman Catholic religion is the religion of the overwhelming majority of Tyrolean. In seizing the film, the Austrian authorities acted to ensure religious peace in that region and to prevent that some people should feel the object of attacks on their religious beliefs in an unwarranted and offensive manner". ${ }^{10}$

\section{3. a) Test of thick concepts}

As 'world-guided' thick concepts analysis, this is an interesting case because is a film with a type of parody or ironic caricature of sacred persons for Christianity. They are not treated with the proper respect according to certain sectors. Under this view, this could be considered blasphemous for certain public, but not necessarily shared by the society as whole.

As 'action-guiding' thick concepts analysis, the question is whether this case of blasphemy should be legally prohibited or regulated in some way. The European Court found in favour of the legal prohibition. It is interesting that the dissenting opinion considered it lawful to exhibit this film but restrict it's viewing to adults, in an 'art cinema' exhibition, and provide proper warnings of its content. This has the consequence that from the externalist approach "not everyone" could consider this case blasphemous and therefore they should not blaspheme. From the internalist approach, within a Christian community, this has the meaning of blasphemy and so not to blaspheme.

\footnotetext{
${ }^{7}$ This the description of the play that was done in the Sentence "The play portrays God the Father as old, infirm and ineffective, Jesus Christ as a "mummy's boy" of low intelligence and the Virgin Mary, who is obviously in charge, as an unprincipled wanton. Together they decided that mankind must be punished for its immorality. They reject the possibility of outright destruction in favour of a form of punishment which will leave it both "in need of salvation" and "capable of redemption". Being unable to think of such a punishment by themselves, they decide to call on the Devil for help." Otto-Preminger Institut v. Austria App no 13470/87 (ECHR, 20 September 1994).

8 ibid, dissenting opinion

${ }^{9} \mathrm{ibid}$, dissenting opinion.

${ }^{10}$ ibid.
} 
As thick concepts community-shared analysis, this is the reason used by the Court to restrict the freedom of speech. It is a version of legal moralism, the protection of the beliefs of the majority of the citizens in that region of Austria. The European Court affirmed that there was a "pressing social need for the preservation of religious peace; it had been necessary to protect public order against the film". ${ }^{11}$ From thick concepts disengaged way analysis, this case could be considered offensive for certain sectors, but not necessarily by all the population because is an ironic and artistic representation. From the thick concepts engaged way analysis, those who live the Christian blasphemy concept could find this case offensive to certain degree.

\section{3. b) Test of civility}

This is a satyricalsatirical film of "art cinema" on the relevant figures of the Christianity. What is offensive is the caricature of persons considered sacred, but this is a particular reason that is not accessible to all. The right to free speech and criticism should be predominant.

\subsection{Wingrove v. United Kingdom 25 November 1996}

The applicant, Mr. Nigel Wingrove, is a film director and did a video work called Vision of Ecstasy, inspired in the life and writings of St. Teresa de Avila. The video describes erotic intimacy between St. Teresa and Christ and other actors.

It is a version of the life of St. Teresa that contains an element of erotic intimacy. For some people this is blasphemous, an offence to the saints or sacred persons. For this case it is important that in the United Kingdom there was a blasphemy law, until 2008, only for the Christian religion. This is because the Church of England is the official religion. This was a problem of religious neutrality of the State. The European Court recognizes that "the uncontested fact that the law of blasphemy does not treat on an equal footing the different religions practised in the United Kingdom does not detract from the legitimacy of the aim pursued in the present context". ${ }^{12}$

On the legitimacy of the crime of blasphemy, the Court had accepted that "respect for the religious feelings of believers can move a State legitimately to restrict the publication of provocative portrayals of objects of religious veneration". ${ }^{13}$

The freedom of creation and art is an important value. The possibility of criticism is fundamental in a democratic society. However, the key point, in the balance between harm and freedom, is when could something be offensive. It is a question of interpretation and a matter of degree. The European Court explains that:

"As regards the content of the law itself, the Court observes that the English law of blasphemy does not prohibit the expression, in any form, of views

\footnotetext{
${ }^{11}$ ibid.

${ }^{12}$ Wingrove v. United Kingdom App no 19/1995/525/611 (ECHR, 25 November 1996).

${ }^{13} \mathrm{ibid}$.
} 
hostile to the Christian religion. Nor can it be said that opinions which are offensive to Christians necessarily fall within its ambit. As the English courts have indicated it is the manner in which views are advocated rather than the views themselves which the law seeks to control. The extent of insult to religious feelings must be significant, as is clear from the use by the courts of the adjectives "contemptuous", "reviling", "scurrilous", "ludicrous" to depict material of a sufficient degree of offensiveness. The high degree of profanation that must be attained constitutes, in itself, a safeguard against arbitrariness". ${ }^{14}$

For the European Court, this case was a serious and offensive attack. The Court observed that "the refusal to grant Visions of Ecstasy a distribution certificate was intended to protect "the rights of others", and more specifically to provide protection against seriously offensive attacks on matters regarded as sacred by Christians".

\section{4. a) Test of thick concepts}

On the 'world guided' thick concepts analysis, the sex life of sacred and holy persons is a taboo. This is a film, an artistic portrait from an imaginated plot, with some characters that represent people of religious significance and, according to certain sectors, they did not show the proper behaviour. Is a kiss between St. Teresa and Christ blasphemous? It is likely that the answer will depend on some contextual factors and religious interpretation of representation in artwork. Another time is linked with the issue of sex life of sacred or saint persons.

On the 'action-guiding' thick concepts analysis, the key point is if the restriction of free speech in this case is justified, like the European Court found in its ruling. If it could be accepted that the film is blasphemous in content and so the next step is to determine whether a total prohibition or a regulation should be applied. As in the previous case dissenting opinion suggested, that regulation could consist of restricting the exhibition to certain places or audiences with proper warnings of the type of content. From the externalist approach, "not everyone" consider this case blasphemous because it is a film that reflects intimacy between two people who have a particular meaning that is not accessible to all. From the internalist approach, within Christian community, this could be considered blasphemous as the sex life of sacred persons is a taboo.

The view is community-shared by some Christian believers, but not by nonChristian believers. This is the main reason for the restriction of speech because it is the majoritarian religion, and officially recognised as a State religion, in the United Kingdom and, in that time, there was a crime of -Christian- blasphemy. From the thick concepts disengaged way analysis, this could be considered offensive for certain sectors, but it is a type of artistic representation. From the thick concepts engaged way analysis, those who live the Christian blasphemy concept could find this case blasphemous.

14 ibid. 


\section{4. b) Test of civility}

A video of the life of a Saint figure, with some scenes of erotic intimacy, which has been regarded as offensive. It could be considered as blasphemous for certain sectors. This is a particular reason, not accessible to all. The right to free speech and the criticism should be predominant.

\subsection{Samina v. Sweden 20 October 2011}

The applicant, Yasmin Samina, is a Pakistani national who was born in 1971 and lives in Uppsala. Having arrived in Sweden in 2007, her application for asylum was refused by an unappealable court decision in 2009. She complained that her extradition to Pakistan would be in violation of, in particular, Article 3 (prohibition of inhuman and degrading treatment), as she would face a risk of being arrested, tortured and executed on charges of blasphemy, either by the authorities or religious fundamentalists due to her activities for a Christian organisation. She also maintained that she would not be able to afford treatment upon her return to Pakistan for her poor mental health.

The US Department of State "2009 Human Rights Report: Pakistan”, 11 March 2010, stated:

"The Penal Code calls for the death sentence or life imprisonment for anyone who blasphemes the Prophet Muhammad. The law provides for life imprisonment for desecrating the Koran and up to 10 years in prison for insulting another's religious beliefs with the intent to offend religious feelings. The latter penalty was used only against those who allegedly insulted the Prophet Muhammad". ${ }^{15}$

According to this, the applicant was involved in these facts involved in these blasphemy laws:

"It was further stated that the applicant and other members of the organisation had received life-threatening calls, letters and text messages. Four times, unknown persons had thrown stones at them. Muslim extremists wanted to kill them and their families because the extremists mistakenly believe that the organisation wants to convert Muslims to Christianity. The last threatening letter had stated that the members of the Franciscan JPIC were "kafar" and that the authors had commenced "jihad" against them and would kill them. They also threatened to have them punished through the blasphemy laws. The organisation had reported this to the police but without results so they had stopped their activities. The Director requested that the applicant be granted asylum in order to save her life". ${ }^{16}$

\footnotetext{
${ }^{15}$ Samina v. Sweden App no 37974/11 (ECHR, 19 December 2013).

${ }^{16}$ ibid.
} 
In this case, the applicant "claimed that both the Pakistani authorities and religious fundamentalists were looking for her and that she would face a real risk of being imprisoned, tortured and perhaps executed on charges of blasphemy upon return". ${ }^{17}$ Finally, in its ruling, "the Court considers there are no indications that the situation in Pakistan is sufficiently serious to conclude that the return of the applicant thereto would constitute, in itself, a violation of Article 3 of the Convention". ${ }^{18}$ This article of the European Convention establishes the "prohibition of inhuman or degrading treatment" and that was the argument on which the claimant sought to rely to avoid being deported to Pakistan.

\section{5. a) Test of thick concepts}

On 'world-guided' thick concept analysis, blasphemy laws in Pakistan should be understood in the context of a Muslim country. More specifically, in the context of what could be considered blasphemous in the Muslim religion. This religion has a special protection for certain figures or dogmas, like Prophet Muhammad. However, this case focuses on how Christian religious practice in a Muslim country could be considered a form of blasphemy. Even if the conduct consists of Christian religious proselytism, could this be correctly considered to be a form of blasphemy? This is an ambiguous side of blasphemy because, historically, it was religious orthodoxy that dictated what was blasphemous and what was not. Nowadays, considering Christian religious proselytism as blasphemous clearly opposes religious freedom right.

The 'action-guiding' thick concept analysis is particularly relevant in this case. According to certain sectors of the Pakistani population, the applicant's activities could be considered blasphemous and, as a consequence, could, under Pakistany blasphemy law, subject her to judicial punishment and, also, run the risk of her being subjected to unlawful violence. Historically, the reasons for action to defend religious orthodoxy could be seen as form of intolerance and, in certain cases, could involve violence. This view, that it is intolerance, goes against the Social Contract of living harmoniously together, as a basis for public ethics. On the externalist approach, "not everyone" has a reason not to blaspheme because here blasphemy was synonymous of religious proselytism and pluralism that are core values in democratic societies. On the internalist approach, if the community of reference is Pakistani society, it could be conceived that blasphemy includes Christian proselytism, but this is a local meaning that could be seen as a form of intolerance.

On the 'community-shared' thick concept analysis, the key point is whether this intolerant view on blasphemy, against the practice of other religions, is shared by all Muslims or only by the extremist Muslims. On the thick concepts disengaged way analysis, this use of blasphemy could be shared by certain sectors in some Muslim countries, but not in a global stance referring to the respect for human rights, especially from Western countries. On the thick concepts engaged way analysis, this type of understating of blasphemy as intolerance or the guardian of religious orthodoxy, could only be maintained by those who live the concept within a fundamenlist faith.

\footnotetext{
17 ibid.

18 ibid.
} 


\section{5. b) Test of civility}

The fact that religious proselytism is violently and legally prosecuted clearly goes against public reason and has a particular meaning, no accessible to all. It is a violent form of intolerance against the overlapping consensus of "reasonable comprehensive" doctrines in Rawls' tems.

\subsection{Case I.A. v. Turkey 13 September 2005}

In November 1993 a novel by Abdullah Rıza Ergüven entitled "Yasak Tümceler" ('The forbidden phrases') was published. The book conveyed the author's views on philosophical and theological issues in a novelistic style.

In an indictment of 18 April 1994 the Istanbul public prosecutor charged the applicant under article $175 \S \S 3$ and 4 of the Turkish Criminal Code with blasphemy against 'God, the Religion, the Prophet and the Holy Book' through the publication of the book in question.

It is a novel on ideas about Islam that was published in a majoritarian Muslim country. The public prosecutor's indictment was based on an expert report drawn up at the request of the press section of the Istanbul public prosecutor's office by Professor Salih Tuğ, dean of the Theology Faculty of Marmara University at that time. In his report of 25 February 1994 this expert observed:

"[...] Although these passages may be regarded as a polemic in support of the author's philosophical views, it may be observed that they also contain statements that imply a certain element of humiliation, scorn and discredit vis-à-vis religion, the Prophet and belief in God according to Islam ... In the author's view, religious beliefs and opinions are mere obscurities, and ideas based on nature and reason are described as clear-sighted. The author describes religious faith as a 'desert mirage', a 'primitive idea' and 'desert ecstasy', and religious practices as 'the primitivism of desert life' [...]”. ${ }^{19}$ particular:

In his report the expert quoted numerous passages from the book under review, in

"The imaginary god, to whom people have become symbolically attached, has never appeared on stage. He has always been made to speak through the curtain. The people have been taken over by pathological imaginary projections. They have been brainwashed by fanciful stories ... this divests the imams of all thought and capacity to think and reduces them to the state of a pile of grass ... [regarding the story of the Prophet Abraham's sacrifice] it is clear that we are being duped here ... is God a sadist' ... so the God of Abraham is just as murderous as the God of Muhammad". ${ }^{20}$

\footnotetext{
${ }^{19}$ I.A. v. Turkey Samina v. Sweden App no 42571/98 (ECHR, 13 September 2005).

${ }^{20} \mathrm{ibid}$.
} 
In the balance between harm v. freedom, this is not a case of criticism but an "abusive attack" on the Prophet Muhammad according to the Court:

"...the present case concerns not only comments that offend or shock, or a 'provocative' opinion, but also an abusive attack on the Prophet of Islam. Notwithstanding the fact that there is a certain tolerance of criticism of religious doctrine within Turkish society, which is deeply attached to the principle of secularity, believers may legitimately feel themselves to be the object of unwarranted and offensive attacks through the following passages: 'Some of these words were, moreover, inspired in a surge of exultation, in Aisha's arms. [...] God's messenger broke his fast through sexual intercourse, after dinner and before prayer. Muhammad did not forbid sexual intercourse with a dead person or a live animal'". ${ }^{21}$

It is important because this is a case of the European Court in protection of religious feeling of a Muslim country. The argument used by the Court for the ruling is based in legal moralism as some other cases. It also justifies certain protection of matters considered sacred according to national authorities. In this respect the Court considers that "the measures taken in respect of the statements issued were intended to provide protection against offensive attacks on matters regarded as sacred by Muslims. In that respect it finds that the measure may reasonably be held to have met a "pressing social need".

\section{6. a) Test of thick concepts}

On 'world-guided' thick concepts analysis, this case is a novel with opinion on Islam figures and dogmas. The most controversial phrase could be considered when the author states: "Muhammad did not forbid sexual intercourse with a dead person or a live animal". This is an interpretation of some Islamic rules, but certain sectors could consider them as blasphemous and offensive. The point here is if there is any kind of possible ambiguity or it is clearly a false accusation.

On 'action-guiding'thick concepts analysis, whether or not the restriction of speech was justified in this case needs to be properly analysed. This depends on the possible falsity of this statement about the Prophet's beliefs. From the externalist approach, "not everyone" thinks this to be blasphemous as this could form part of an open discussion of a historical fact. From the internalist approach, within Muslim community, this could be considered blasphemous.

The important point is that this is an attack on Islam in a Muslim country. A nonbeliever could be interested not in being misinformed with biased and false information about Islam, but the European Court followed the line of legal moralism. In this case, in a Muslim country. From the thick concepts disengaged way analysis, this case is about information on a religion founder that could be seen as offensive if it is not true. From the thick concepts engaged way analysis, those who live the Muslim blasphemy concept, this information is blasphemous.

\footnotetext{
21 ibid.
} 


\section{6. b) Test of civility}

This is a novel that criticises Islam and Prophet's figure and beliefs and made some statements that could be false. Defending against false accusations against is a reason accessible to all. This could be considered a case of collective defamation. However, the open discussion and criticism of religious dogmas is essential part of public reason, but the use of lies or false arguments should not be accepted. As Dacey explains: "for the policies that permitted the circulation of "The Forbidden Phrases" were no calibrated to offend them, denigrate their concerns, or deny their autonomy, but rather to create and sustain social practices of communication that would enable their own views to be heard and registered in public opinion", ${ }^{22}$

\subsection{E.S. v. Austria, 25 October 2018}

In another case, from January 2008, the applicant held several seminars entitled "Basic Information on Islam", opened to the public and was covered by a journalist. The most controversial statement she made was, referring to Muhammad "he was a warlord, he had many women, to put it like this, and liked to do it with children. And according to our standards he was not a perfect human". ${ }^{23}$ The national Courts focused their analysis on the accusation of Muhammad's paedophilic tendencies.

This case was not about a literary exercise, but about some informative seminars on Islam covered by a journalist. Section 188 of the Austrian Criminal Code established the disparagement of religious doctrines, which was a type of religious insult, as a crime. ${ }^{24}$ The accusation of paedophilia against Muhhamad is not new and it corresponds with certain Orientalist and exotic tradition to describe Muslim customs, particularly focused on the Prophet Muhammad (Rosli, Omar, 2017, 78-82).

The European Court of Human Rights, in conclusion, "considers that the domestic courts did not overstep their - wide - margin of appreciation in the instant case when convicting the applicant of disparaging religious doctrines. Accordingly, there has been no violation of Article 10 of the Convention". ${ }^{25}$

\section{7. a) Test of thick concepts}

As 'world-guided' thick concept analysis, this case is different from the previous analysed cases because it was an informative seminar on a religion, not literature. It was

\footnotetext{
${ }^{22}$ Dacey (n 2) 81.

${ }^{23}$ E.S. v. Austria App no 38450/12 (ECHR, 25 October 2018).

${ }^{24}$ The wording of this article is: "Whoever, in circumstances where his or her behaviour is likely to arouse justified indignation, publicly disparages or insults a person who, or an object which, is an object of veneration of a church or religious community established within the country, or a dogma, a lawful custom or a lawful institution of such a church or religious community, shall be liable to up to six months' imprisonment or a day-fine for a period of up to 360 days."Art. 188 of the Austrian Criminal Code. E.S. v. Austria App no 38450/12 (ECHR, 25 October 2018).

${ }^{25}$ E.S. v. Austria App no 38450/12 (ECHR, 25 October 2018).
} 
not a case of the offence of blasphemy, but religious insult that in the Austrian criminal code was neutrally conceived for the "church or religious community established within the country". This included Muslim religion.

The statement that the founder of a religion had paedophilic tendencies could be considered offensive for the followers of that religion. There is, however, a degree of disagreement based on the possibility as to whether that statement was true or not. In Western countries, the sexuality of Muhammad has been object of Orientalist and exotic explanations that includes polygamy, slavery, harem and paedophilia (Rosli, Omar, 2017, 68-82).

The phrase "Muhammad had paedophilic tendencies" could be considered offensive for certain sectors. As an accusation it must be proved to be true or false. On the 'action guiding' thick concepts analysis this case could be seen a form a collective defamation. However, if the alleged defamatory statement can be shown to be true, there is no defamation and so no grounds to restrict the speech. On the externalist approach, "not everyone" has a reason not to blaspheme in this case because it was an statement on the biography of a historical personage that could be open to debate. On the internalist approach, it depends on the community of reference: Society as whole could use the word blasphemy without necessarily including this statement, although the Muslim minority clearly could not.

On the 'community shared' thick concept analysis, the notion of blasphemy in this case could be shared by certain sectors of the believers. On the thick concepts disengaged way analysis, it could be understood, not necessarily shared, this case could be offensive for certain sectors. However, this is a statement of a historical fact about a public person. On the thick concepts engaged way analysis, for those who live the concept, this could be seen as a case of Muslim blasphemy.

\section{7. b) Test of civility}

Religious insult based the figure of the Prophet Muhammad by accusing him of paedophilic tendencies could be seen in a broader level of debate of the historical facts on persons with religious meaning. Falsely accusing Muhammad of practising paedophilia could be considered a way of collectively defaming the Muslim religion, but if this accusation is true, there is no justification for restricting the speech. However, since there has been a traditional ambiguity in the interpretation of these historical facts, this blasphemy would have a particular meaning, not accessible to all. Free speech and criticism must be predominant.

\section{SOME CONCLUSIVE REMARKS}

Blasphemy has been defined as the "act of expressing contempt or a lack of reverence for God or sacred things". Someone could be forgiven for thinking that there is little future for blasphemy as an offence. However, Muslim countries support the view that blasphemy should be regulated, in a reinforced way, at an international level and, as has 
been seen, the case law from the European Court of Human Rights has generally favoured - to some people's surprise! - restricting speech in cases of blasphemy. Dacey criticises that particularly problematic is the Court's doctrine of the margin of appreciation, which gives national authorities broad discretion in interpreting limitations on fundamental rights. In the European context, such discretion has been tolerable because of the relative weakness of the anti-blasphemy legal regimes, where punishments are relatively mild or "proportional". ${ }^{26}$

Understanding blasphemy as a thick concept is useful to explain this European Court case law. The first two cases are X Ltd. and $Y$ v. United Kingdom -1982- and Choudhury v. United Kingdom -1991- in which the Court found in favour of restricting the speech and of not to restricting it, respectively.

From the combination of the internalist approach and the engaged way thick concepts analysis, for those who live the concept of blasphemy, there is a clear problem with the definition of the community of reference for both approaches. If, in each case, the attacked religious community is chosen as reference, from the engaged way thick concepts analysis, both are cases of blasphemy, one for Christians and the other for Muslims. In $X \mathrm{Ltd}$. and $Y$, the community of reference was the majority of the society while in Choudhury, it was the minority. The key point is the legal protection in both cases was only for the religion of the majority. There was a lack of neutrality and equality between different religions and the State.

In the cases Otto-Preminger Institut v. Austria -1994- and Wingrove v. United Kingdom -1996-, the European Court found in favour of restricting the speech. In both cases, the community of reference was clear: the society as whole with a majority of Christian believers. The internalist approach and the engaged way thick concepts analysis were implicitly used in the justification of the European Court in these two cases. This was based on some presumptions, such as society comprising a majority of Christian believers; those who use the concept of blasphemy have a reason not to blaspheme, and those who live the concept of blasphemy think these two cases as blasphemous and offensive.

It could be argued, however, from the externalist approach and the disengaged way thick concepts analysis, that not "everyone" would agree these two cases are blasphemous. From the objectionable concepts viewpoint, the blasphemous meaning attributed by the European Court in these two cases could be controversial, especially if it involves the restriction of speech.

In the case Samina v. Sweden -2011-, blasphemy was seen as a part of the legal arguments of an asylum seeker. The community of reference was a country -Pakistanwith Islam as the majoritarian religion. The interpretation from the internalist approach and in the engaged way thick concepts analysis, could arrive at the conclusion that Christian proselytism is blasphemous in a Muslim country. The externalist approach and the disengaged way thick concepts analysis opposes to this view and maintain that activity was not blasphemous

\footnotetext{
${ }^{26}$ ibid 67.
} 
The cases I.A. v. Turkey-2005- and E.S. v. Austria-2018- are based on different type of accusations about the Prophet Muhammad. In the first case, the community of reference is a country that has Islam as the majoritarian religion and in the second, a country that has Christianity as the majoritarian religion. Both cases presented certain facts attributed to Muhammad. The European Court found in favour of restricting speech in both cases. From the thick concept analysis, the European Court applied the internalist approach and the engaged way with the Muslim believers as community of reference. However, it is possible to argue "not everyone" would find these two cases blasphemous, as could be suggested from the externalist approach and the disengaged way thick concepts analysis. The criticism of religions and the critical historical facts review supports the view that restricting speech in these two cases was not justified.

If thick concepts analysis could properly explain the current European Court of Human Rights case law, it could also provide an alternative view. As previously analysed, the European Court has usually followed an interpretation that includes the internalist approach and the engaged way thick concepts analysis. With the exception of Choudhury, the community of reference for the Court has been the believers of the attacked religion. In postsecular societies, religions still have a role but secularism and diversity should be ensured by the State. This means to decide these blasphemy cases is needed to include also the externalist approach and the disengaged way thick concepts analysis.

The blasphemy ECHR case law have to pass the test of civility - Rawls, Habermas - and, as has been seen, in all cases free speech should prevail in ruling of blasphemy. The freedom of creation of literary and artistic works should prevail because offences against sacred figures or God have a particular meaning — explained because blasphemous is a thick concept - and cannot be translated into secular reasons. The accusations against the Prophet Muhammad form part of a public discussion on historical facts and religious criticisms, and the particular/thick concept of the insult to the Prophet cannot be translated into secular reasons. The Samina case is an example of the dark side of blasphemy as a way to impose religious truth and obviously is incompatible with public reason and the duty of civility.

It can be concluded that thick concepts analysis is useful to explain and justify European Court of human rights blasphemy case law. However, as has been shown blasphemy could be better understood as an objectionable thick concept. This means that the evaluations behind this category are not commonly shared. This has been explained by the externalist approach and the disengaged way thick concept analysis.

The paradox is that in free and democratic societies, a proper balance between the respect for the sacred values and figures -which are highly regarded by believers- and the rights and liberties usually associated with free speech, creative and artistic freedom and free criticism and fear of censorship -which are highly regarded by citizens- is needed. There are many cases balancing respect and freedom, but thick evaluations cannot be easily translated into values that are accessible to all and on which public reason and the duty of civility are based. 


\section{BibLIOGRAPHY}

BENBAJI, Y.; Fisch, M. (2004), "Through thick and thin: A defense of cultural relativism", The Southern Journal of Philosophy, XLII, pp. 1-24.

BLACKBURN, S. (1990), "Hume and thick connections", Philosophy and Phenomenological Research 50, pp. 237-250.

BLACKBURN, S. (1992), "Through thick and thin", Proceedings of the Aristotelian Society, Suplementary Volumes 66, pp. 285-299.

COMMISSION OF VENICE (2010), Blasphemy, insult and hatred: finding answers in a democratic society, Council of Europe, Strasbourg.

DACEY, A., (2012) The future of blasphemy. Speaking of the sacred in an age of human rights, Continuum, United States.

DANCY, J. (1995), "In defense of thick concepts" Midwest Studies in Philosophy XX. pp. 263-279.

ENOCH, D.; Toh, K. (2013), "Legal as a Thick concept", in Waluchow, W., Sciaraffa, S. (eds.), Philosophical foundations of the nature of Law, Oxford University Press, Oxford, pp. 257-278.

ESTLUND, M. (2011), “What are Thick Concepts?”, Canadian Journal of Philosophy 41(1), pp. 25-49.

FISS, J.; Kestenbaum, J. (2017) "Respecting rights. Measuring the World's blasphemy laws", US Comission on International Religious Freedom.

FLAKNE, A. (2005), “Through thick and thin: Validity and reflective judgment", Hypatia, 20 (3), pp. 115-126.

FOOT, Ph. (1958), “Moral arguments” Mind, 67, pp. 502-513.

FOOT, Ph. (2002) Virtues and vices, Claredon Press., Oxford.

FORTE, D. F. (1994), “Apostasy and blasphemy in Pakistan”, Connecticut Journal of International Law, vol. 10, pp. 27-68.

GIBBARD, A. (2003), "Thin and thick", The Journal of Philosophy, vol. 100, num. 6, pp. 288-304.

HABERMAS, J. (2005a), "Religion in the Public Sphere", Holberg Prize Laureate Professor Jürgen Habermas, pp. 10-19.

HABERMAS, J. (2005b), "Faith and knowledge" in Mendieta, E. (ed.) The Frankfurt School on Religion, Routledge, New York and London, pp. 327-337.

HABERMAS, J. (2008), "Notes on Post-secular society”, NPQ, pp. 17-29.

HABERMAS, J. (2014), Between naturalism and religion, Polity.

HARE, R. M. (1963), Freedom and reason, Oxford University Press, Oxford.

HARE, R. M. (1970), The language of morals, Oxford University Press, Oxford. 
HARE, R. M.(1985), “Ontology in ethics” in Ted Honderich(ed.), Morality and objectivity, Routledge \& Kegan Paul, pp. 39-53

HUME, D. (1990), A treatise of human nature, Claredon Press, Oxford.

HUME, D. (1988), Concerning human understanding and concerning the principles of morals, Claredon Press, Oxford.

HURTSHOUSE, R. (2001), On virtue ethics, Oxford University Press, Oxford.

JONES, P. “Offesiveness and Law”, British Journal of Political Science, vol. 10, num. 2, 1980, pp. 129-148.

LEVY, L. W., (1995), Blasphemy. Verbal offense against the sacred from Moses to Salman Rushdie, The University of North Carolina Press, United States.

MARSHALL, P. (2012), “Blashemy and free speech”, Imprimis, vol. 41, num. 2.

MCDOWELL, J. (1979) "Virtue and reason", The Monist, 62 (3) pp. 331-350

MCDOWELL, J. (1984), "Wittgenstein on following a rule”, Synthese, 58, pp. 325-363.

MOORE, G.E. (1993), Principia Ethica, Cambridge University Press, Cambrigde, United Kingdom.

MOORE, A.W. (2006a), "Maxims and thick ethical concepts”, Ratio, num. XIX, vol. 2, pp. 129-147.

MOORE, A.W. (2006b), "Introduction" in Williams, B., Philosophy as humanistic discipline, Princeton University Press, pp. XI-XIX.

MORTENSEN, Reid (1994), "Blasphemy in a secular state: a pardonable sin?", UNSW Law Journal, 17(2), pp. 409-431.

MODOOD, T. (2007), Multiculturalism. A civic idea, Polity., Cambridge.

MODOOD, T. (2010), "Moderate secularism, religion as identity and respect for religion" The Political Quaterly, 81, pp. 4-14.

NASSERA ZINI, S. (2015), "El 9/11 y la teoría del choque de las civilizaciones entre Occidente y el Mundo Árabe: la vision intermedia de Naguid Mahfouz", Tesis Doctoral, Departamento de Periodismo, Universidad de Málaga.

NITISOR, A-T. (2007), "Speaking the depicable: Blasphemy in Literature”, JSRI, núm. 6, pp. 69-79.

PAREKH, B. (1990), “The Rushdie Affair: Research agenda for Political Philosophy”, Political Studies, XXXVIII pp. 695-709.

PAREKH, B. (2000), Rethinking multiculturalism. Cultural diversity and Political Theory, Harvard University Press, Cambridge, MA 2000.

PAREKH, B. (2008), A new politics of identity: Political principles for an interdependent world, Palgrave MacMillan, New York.

PRINGLE, H. (2011), "Regulating offence to the godly: Blasphemy and the future of religious vilification laws", UNSW Law Journal, 34, (1), pp. 316-332. 
RAWLS, J. (1996) Political liberalism, Columbia University Press, United States.

RAWLS, J. (1997) “The idea of Public Reason Revisited”, The University of Chicago Law Review 64 (3), pp. 765-807.

ROSLI, M. B. N. U.; Omar, N. (2017), "References to sexuality in relation to the Prophet Muhammad (pbuh) in $17^{\text {th }}-19^{\text {th }}$ Century selected French and English Orientalist travelogues", Arab World English Journal for translation and Literacy Studies, 1 (4), pp. 78-82.

SAJÓ, A. (2008), "Preliminaries to a concept of constitutional secularism" I CON, 6 (3), pp. 605-629.

SAJÓ, A. (2009) "Constitutionalism and secularism: The need for public reason" Cardozo Law Review 30, pp. 2401-2429.

SCANLON, T.M. (2003), "Thickness and Theory", The Journal of Philosophy, 100 (6), pp. 275-287.

SCHEFFLER, S. (1987) "Through thick and thin a critical notice of Ethics and the limits of Philosophy”), The Philosophy Reviev, 96 (3), pp. 414-434.

SLOTE, M. (1995), From morality to virtue, Oxford University Press, Oxford.

SLOTE, M.(2011), The impossibility of perfection. Aristotle, feminism and the complexities of ethics, Oxford University Press, Oxford.

SOAGE, A. B. (2006), "The Danish caricature seen from the Arab World", Totalitarian Movements and Political religions, vol. 7, núm 3, pp. 363-369.

SWANTON, C. (2005), Virtue ethics. A pluralistic view, Oxford University Press, Oxford.

TAYLOR, C. (2007), A secular age, The Belknap Press of Harvard University Press, United States.

TAYLOR, C. (2009), "What is secularism?” in Brahm Levey, G., Modood, T., Secularism, religion and multicultural citizenship, Cambridge University Press, pp. xi-xxiv

UNGUREANU, C. (2016), "Uses and abuses of postsecularism” in Requejo, F.; Ungureanu, C. (eds.), Democracy, Law and religious pluralism in Europe, Routledge.

US COMMISSION ON INTERNATIONAL RELIGIOUS FREEDOM (2014), Policy Brief Prisoners of Belief, Individuals jailed under Blasphmey laws.

VÄYRYNEN, P. (2003), The Lewd, the rude and the nasty. A study of thick concepts in ethics, Oxford University Press, Oxford.

VÄYRYNEN, P. (2009), "Objectionable thick concepts in denials" Philosophical Perspectives 23, pp. 440-469.

WILLIAMS, B. (2011) Ethics and the limits of Philosophy, Routledge, London and New York, 2011.

ZUCCA, L. (2012), A secular Europe. Law and religion in European constitutional landscape, Oxford Unity Press, Oxford. 